\title{
FENOMENA GUGATAN CERAI DARI KALANGAN ISTRI TERHADAP SUAMI (Studi Kasus Pada Pengadilan Agama Kabupaten Malang)
}

\author{
Siti Nurul Nikmatul Ula ${ }^{1 *}$, La Basri $^{2}$, Uswatul Mardliyah ${ }^{3}$ \\ Program Studi Sosiologi, FISIP, Universitas Muhammadiyah Sorong, Indonesia \\ *Korespondensi: sn396396@gmail.com
}

\begin{abstract}
The increasing number of divorces from year to year at Malang Regency on Religious Court, especially divorce claims by wife towards the husbands. The purpose of this study was to determine the factors of divorce, changes in shifting social values and the meaning of divorce for women. The method used in this study is a qualitative approach and descriptive form as a research procedure that produces descriptive data in the form of written or spoken words from people which can be observed. The results showed that there were several factors causing a divorce suit (violence both physically and non-physically, neglecting husband's responsibility and economic needs), but each of these factors did not stand alone as a single factor, but rather a series of causes which at one point that couple can decide to divorce. From the problem above, it found that there is a shift in social values in society causing divorce to be no longer a taboo thing to do and a change in function in the family that is replaced at this time, and it can be seen that there is a meaning of divorce for divorced women (as a way out of problems, freedom and economic independence). So if the process develops, it will make the wife more courageous to break the relationship first if there are things that make her marriage unsustainable.
\end{abstract}

Keywords: Divorce Lawsuit, Social Change, Shifting of Social Values

\begin{abstract}
ABSTRAK
Meningkatnya angka perceraian dari tahun ketahun pada Pengadilan Agama Kabupaten Malang, khususnya gugatan cerai yang dilakukan istri terhadap suami. Tujuan dalam penelitian ini untuk mengetahui faktor perceraian, perubahan pergeseran nilai sosial dan makna perceraian bagi wanita. Metode yang digunakan dalam penelitian ini adalah dengan pendekatan kualitatif dan berbentuk diskriptif sebagai prosedur penelitian yang menghasilkan data deskriptif berupa kata-kata tertulis atau lisan dari orang-orang dan perilaku yang dapat diamati. Hasil penelitian menunjukkan bahwa terdapat beberapa faktor penyebab terjadinya gugatan cerai (kekerasan baik secara fisik dan non fisik, melalaikan tanggung jawab suami dan kebutuhan ekonomi), akan tetapi setiap faktor tersebut tidaklah berdiri sendiri sebagai faktor tunggal, melainkan merupakan satu rangkaian sebab yang pada satu titik membuat pasangan memutuskan untuk bercerai. Dari hal tersebut ditemukan bahwasannya terdapat pergeseran nilai social dalam masyarakat menyebabkan perceraian bukan lagi hal yang tabu untuk dilakukan dan adanya perubahan fungsi dalam keluargayang tergantikan pada saat ini, serta dapat diketahuiterdapatmakna perceraian bagi wanita bercerai (sebagai jalan keluar dari masalah, kebebasan dan kemandirian secara ekonomi). Maka jika dengan semakin berkembangnya proses tersebut, maka semakin membuat istri berani untuk memutuskan hubungan terlebih dahulu perkawinan jika terdapat hal-hal yang membuat perkawinannya tidak dapat dipertahankan lagi.
\end{abstract}

1 Fenomena Gugatan Cerai.... 


\section{Kata Kunci :Gugatan Cerai, Perubahan Sosial, Pergeseran Nilai Sosial}

\section{PENDAHULUAN}

Keluarga bahagia lahir dan batin adalah dambaan setiap insan, namun dalam proses perjalanannya pasti ada rintangan dan permasalahan yang terjadi dan apabila semakin lama permasalahan tersebut tidak terdapat penyelesaiannya maka bisa menjadikan kearah perceraian (Karim, Erna : 1999).

Proses perceraian di Indonesia dilakukan di Pengadilan Agama (khusus untuk yang beragama Islam) atau di Pengadilan Negeri (khusus untuk yang non-Islam). Padahal Indonesia masih menganut budaya ketimuran yang seharusnya mensakralkan arti sebuah perkawinan, Namun fakta berkata lain, angka perceraian yang kerap meningkat dan bahkan dinyatakan secara kuantitatif meningkat setiap tahunnya. Hal ini dinyatakan pada data grafik batang di Pengadilan Agama Kabupaten Malang untuk perkara perceraian.

Angka Talak dan Gugat Cerai Pengadilan Agama Kabupaten Malang Tahun 2010 - 2014 (Ribuan Perkara)

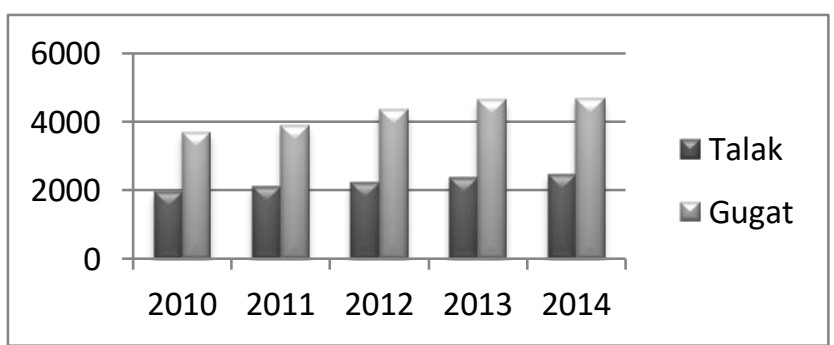

Sumber : Pengadilan Agama Kabupaten Malang
Data diatas menunjukkan terjadinya kenaikan angka perceraian di Kabupaten Malang pada tahun 2010 sampai 2014, khususnya gugat cerai yang semakin tinggi tiap tahunnya.

Pada data grafik batang diatas, terdapat berbagai macam alasan penyebab perceraian pada Kantor Pengadilan Agama Kabupaten Malang dari faktor moral (poligami, krisis ahlak, cemburu), meninggalkan kewajiban (kawin paksa, ekonomi, tidak tanggung jawab), menikah dibawah umur, Menyakiti Jasmani (kekejaman jasmani dan mental), dihukum, cacat biologis, dan lain-lain, akan tetapi tampaknya setiap alasan tersebut tidaklah berdiri sendiri sebagai faktor tunggal, melainkan merupakan satu rangkaian sebab yang pada satu titik membuat pasangan memutuskan untuk menempuh proses perceraian. Sehingga dapat disimpulkan bahwa di dalam masyarakat ada semacam fenomena pada kasus perceraian yang awalnya merupakan suatu perbuatan yang biasanya dilakukan oleh pria, namun sekarang ini juga cenderung dapat dilakukan oleh wanita.

Masalah ini menjadi menarik untuk dibahas dan diteliti lebih lanjut jika dilihat dari masyarakat sekarang ini. Kalau dicermati kemasa lalu atau zaman dahulu peran suami bekerja, mencari nafka untuk keluarga, sedangkan seorang istri hanya mempunyai peran 


\section{Noken Vol. 6 (No. 1) Halaman: 63-74 2020}

dirumah, seperti memasak, mengasuh anak dan lain-lain, oleh sebab itu istri bergantung pada suami dikarenakan istri tidak mempunyai penghasilan sendiri. Secara sosial, dimasyarakat masih memandang bahwa gugatan cerai istri terhadap suami sebagai sesuatu hal yang negatif dan tabu untuk dilakukan, sehingga hal tersebut sebagai sesuatu hal yang memalukan dan harus dihindari. Jadi apapun bentuk situasi dan kondisi yang dihadapi dan dirasakan dalam perjalanan perkawinan mereka sedapat mungkin dipertahankan.

Pada saat ini peran keduanya sudah berbeda. Nur Aisyah (2013), mengatakan peran istri tidak hanya sebatas dilingkungan rumah, dimana istri zaman sekarang bisa menjadi wanita karir bagi seorang istri jika diperbolehkan oleh suami guna menopang kebutuhan dalam rumah tangganya, sehingga dapat membantu meringankan beban suami dalam mencari nafka berupa materi untuk keluarga dan pandangan masyarakat pada saat ini tidak lagi memandang perceraian sebagai hal yang memalukan dan harus dihindari, karena jika itupun terjadi masyarakat dapat dengan mudah memahami dan mentoleransi perceraian tersebut sebagai suatu alternatif jalan terbaik bagi pasangan itu.

Namun jika dikaitkan dengan fenomena yang terjadi pada saat ini dapat diidentifikasikan bahwa terdapat perubahan pola pikir masyarakat yang mulai mengalami kemajuan dikarenakan alkulturasi budaya modern dan adanya pergeseran nilai sosial budaya dalam institusi keluarga, yang mana bagi mereka (istri) yang memilih lebih baik bercerai, hidup tanpa dengan pasangan (suami) daripada hidup dalam suatu perkawinan yang tidak membahagiakan dianggap sebagai langkah atau jalan keluar dari masalah. Berkaitan dengan adanya makna yang pertama, selanjutnya perceraian itu sendiri dianggap sebagai bentuk kebebasan (makna kebebasan) yang artinya dapat dikatakan pada umumnya mereka merasakan bebas dari kekuasan suami dan kewajiban lainnya dan sebagai bentuk kemandirian (makna kemandirian), yang dimana sebelumnya istri pada umumnya sangat bergantung pada nafkah yang diberikan suami, akan tetapi pada saat ini perempuan tidak lagi tergantung pada suami baik secara ekonomi maupun psikologis (Fachrina \& Aziwarti, 2006).

Perubahan seperti halnya diatas didukung oleh beberapa kenyataan seperti persentasi wanita bekerja yang terus mengalami peningkatan, adanya gerakan - gerakan yang menuntut persamaan hak-hak antara laki-laki dan wanita yang telah muncul sejak abad ke 20, dan timbulnya gerakan feminisme yang memperjuangkan perlunya kebebasan bagi kaum wanita.

Bukan hanya hal-hal diatas saja yang dapat mempengaruhi, akan tetapi ada beberapa faktor lain yang menyebabkan tingginya perubahan tersebut (Bakhtiar Hasan A.M: 2009) yaitu; 1) 


\section{Noken Vol. 6 (No. 1) Halaman: 63-74 2020}

Adanya tekanan-tekanan social dari lingkungan baik keluarga,teman dan masyarakat sekitar terhadap pentingnya arti ketahanan sebuah perkawinan semakin berkurang, gejala individualis semakin mencuat dengan menjadikan persoalan rumah tangga adalah urusan mereka sendiri; 2) Adanya kemajuan dalam bidang iptek yang memungkinkan semuanya dapat tersedia dan memberikan kemudahan-kemudahan dalam pemenuhan kebutuhan hidup membuat situasi saling ketergantungan antara pasangan suami istri melemah; 3) Peralihan fungsi-fungsi keluarga kepada lembaga lainnya di luar keluarga memberikan alternatif baru yang semakin mengurangi saling ketergantungan tersebut.

Idealnya dalam kondisi yang demikian eksistensi keluarga tidak rentan lagi terhadap hal-hal yang membuat mereka memutuskan untuk melakukan perceraian.

Melalui pemahaman permasalahan yang terjadi diatas secara mendalam, diharapkan dapat mengungkapkan fenomena gugatan cerai dari kalangan istri terhadap suami.

\section{METODE}

Penelitian ini berusaha memaparkan realitas yang menggambarkan suatu keadaan beserta segala aspeknya dalam rangka pemberian informasi sejelas-jelasnya tentang fenomena gugatan cerai dari kalangan istri terhadap suami di Pengadilan Agama Kabupaten Malang, maka metode yang digunakan adalah pendekatan kualitatif dan berbentuk diskriptif sebagai prosedur penelitian yang menghasilkan data deskriptif berupa kata-kata tertulis atau lisan dari orang-orang dan perilaku yang dapat diamati (Burhan Bungin : 2007). Jenis penelitian ini adalah studi kasus dengan tujuannya untuk mendapatkan masukan - masukan dari segi pandangan wanita itu sendiri mengenai makna perceraian, faktor penyebab perceraian, aspek kehidupan keluarga, dan perkawinan. Sebagaimana prosedur perolehan data penelitian kualitatif (Sugiyono: 2011), data diperoleh dari observasi dengan mengamati secara langsung proses pelaksanaan gugatan cerai, wawancara yang dilakukan dengan informan yang sedang melakukan gugatan perceraian yang memiliki kreteria (umur antara 18 tahun - 38 tahun, dengan masa perkawinan kurang dari 10 tahun dan berdomisili di daerah kabupaten malang serta masyarakat sekitar pengadilan) dan dokumentasi yang berupa vidio, foto, surat-surat dan arsip yang berkaitan dengan gugatan cerai. Setelah data-data terkumpul, kemudian di analisis dan disajikan sesuai variabel-variabel yang dijadikan indikator-indikator dalam penelitian ini, untuk selanjutnya dapat memberikan gambaran yang jelas tentang Fenomena Gugatan Cerai dari Kalangan Istri Terhadap Suami

\section{HASIL DAN PEMBAHASAN}

Faktor Penyebab Terjadinya Gugatan Cerai 


\section{Noken Vol. 6 (No. 1) Halaman: 63-74 2020}

Perceraian adalah sebagai upaya terakhir setelah gagal dilakukan upaya perdamaian antara pasangan suami istri (Su'adah,2005). Hal ini hendaknya hanya dilakukan dalam suatu keadaan ketika jalan lain untuk memperbaiki kehidupan rumah tangga sebab tidak mungkin diketemukan lagi. Dari hasil penelitian dengan mewawancarai informan penelitian yang berada di pengadilan di pengadilan, dengan Bapak Fanani selaku hakim dan Bapak Herdi selaku panitia yang berada pada POSBAKUM (Pusat Bantuan Hukum), mengatakan bahwa penyebab atau faktor terjadinya perceraian menurut beliau berikut ini;

"Penyebabnya sangat fariatif karena penyebab terjadinya perceraian tersebut bias merembet kepada persoalan yang lain, seperti factor ekonomi dan perselisihan yang terus menerus terjadi, bisa menyebabkan terjadinya kekerasan baik seksual maupun psikis, yang menurut Undang-Undang kekerasan tersebut masuk pada kategori KDART (Kekerasan Dalam Rumah Tangga) yang pada akhirnya menyebabkan salah satu pihak meninggalkan rumah".

Selanjutnya dari hasil penelitian dengan mewawancarai beberapa informan yang melakukan gugatan cerai ditemukan alasan alasan mengapa mereka melakukan perceraian, hal ini terlihat dari jawaban yang dikatakan oleh seorang wanita muda bernama mila 23 tahun mengungkapkan bahwa;

"Suami saya sebenarnya orang yang bertanggung jawab, meskipun uang belanja hanya diberikan secukupnya, akan tetapi pada saat suami di PHK dari tempat kerja, suami sudah jarang memberi nafkah dan kadang tidak sama sekali. Saya menerima saja karena sebagai istri saya tidak banyak menenuntut sebab saya juga bekerja. Setelah beberapa bulan suami tidak juga mendapat pekerjaan karena walaupun saya mencarikan, suami tidak mau dengan alasan gaji yang diterima lebih sedikit dari gaji yang dahulu, ditambah lagi suami sudah jarang pulang kerumah dan apabila berada dirumah tidak jarang terjadi pertengkaran dan perselisihan diantara kita yang mana suami sering menghina, mencaci dan menfitnah saya".

Selanjutnya pada informan lain yang

berbeda, diungkapkan oleh ibu aisyah yaitu:

"Saya dan suami sama-sama mempunyai pekerjaan yang sama dengan penghasilan lumayan cukup untuk menghidupi keluarga tiap harinya. Akan tetapi sifat suami yang sering berjudi dan pulang dalam keadaan mabuk membuat keuangan menjadi berantakan atau tidak jelas,dan sering kali saya juga harus menanggung hutang suami dari kalah judi. Dan kalaupun saya tidak bisa membantu membayar hutang judinya pasti suami akan marah besar dengan katakata menghina, memaki, tak jarang suami melakukan kekerasan fisik (memukul). Pernah saya menasehati tapi tidak dihiraukan malah saya yang dipersalahkan.

Dari uraian kasus-kasus perceraian di atas dapat dijelaskan bahwa faktor penyebab terjadinya gugatan cerai tersebut dijelaskan adanya variasi faktor yang menyebabkan terjadinya perceraian, dimana faktor penyebab utama secara umum adalah tidak adanya kecocokan mulai dari faktor kekerasan baik fisik maupun non fisik (emosional). Secara emosional dalam hal ini pasangannya sering berteriak-teriak dan mengeluarkan kata-kata kasar yang menyakitkan, cemburu (menuduh tanpa alasan), 


\section{Noken Vol. 6 (No. 1) Halaman: 63-74 2020}

berjudi dan mabuk serta masalah ekonomi (keuangan), yang akhirnya menyebabkan pertengkaran yang sering kali disertai dengan pemukulan oleh suami.

Sehingga dapat ditarik suatu hasil bahwa faktor tersebut tidaklah berdiri sendiri sebagai faktor tunggal melainkan merupakan satu rangkaian sebab, yang membuat informan memutuskan untuk menempuh proses perceraian.hal ini terlihat dari semua informan yang memberikan beberapa alasan (tidak hanya satu) yang menyebabkan perceraian.

\section{Pergeseran Nilai Sosial Budaya Dalam Masyarakat dan Keluarga}

Keluarga merupakan unit terkecil dalam masyarakat, keluarga memiliki kewajiban untuk memenuhi kebutuhan-kebutuhannya yang meliputi agama, psikologi, makan, minum, dan sebagainya (Soerjono Soekanto, 2009). Dalam hal ini dapat dikatakan bahwa masyarakat memberikan suatu toleransi terhadap suatu perceraian,yang mana perceraianmenjadi suatu hal yang umum terjadi dalam masyarakat dan cenderung meningkat tiap tahunnya.Sehingga stigma terhadap perceraian didalam masyarakatpun menjadi umum.

Jika kita lihat pada masa lalu apabila antara suami istri mengalami perselisihan maka masyarakat secara umum dan lingkungan ketetanggaan, kerabat serta teman-teman secara moral ikut bertanggungjawab akan keutuhan dan kelanjutan kehidupan perkawinan pasangan tersebut, akan tetapi pada masa kini tekanantekanan sosial tersebut menjadi berkurang, karena dalam masyarakat menganggap bahwa permasalahan yang terjadi menjadi urusan dan tanggung jawab suami-istri atau keluarga tersebut. Perceraian dalam perkembangannya dapat dikatakan terus mengalami pergeseran seiring dengan pergeseran nilai-nilai atau normanorma yang ada dalam masyarakat mengenai perceraian itu sendiri. Hal tersebut serupa dengan pandangan masyarakat mengenai perceraian, salah seorang informan Bapak Fanani (37 tahun) mengatakan;

"Bahwasannya sebelum mengarah kepada perceraian, setidaknya dilakukan terlebih dahulu secara kekeluargaan untuk menemukan titik temu karena beliau menganggap bahwasannya perceraian sebagai langkah darurat ketika jalan lain sudah tidak mungkin ditempuh, artinya langkah - langkah semaksimal mungkin yang ditempuh mulai dari musyawaroh, mediasi, melakukan pembicaraan mengenai solusi jalan keluar dari permasalah yang terjadi dan jika jalan yang dilalui tersebut tidak memungkinkan untuk disatukan kembali maka tidak ada jalan lain selain perceraian maka tidak ada salahnya untuk dilakukan karena itu jalan yang diberikan oleh Agama dan Hukum ketika situasinya dalam keadaan darurat. Jika dahulu seorang perempuan dipukuli suami karena ada hadis yang mengatakan tidak boleh melawan apapun yang dilakukan dia diam saja, tanpa ada proses pemaknaan karena untuk kesadaran hukum kurang dan aksesnyapun tidak ada. Akan tetapi lain halnya pada saat ini tidak, ada perlawanan karena ada ruang hukum, dimana kesadaran hukum perempuan lebih tinggi, tingkat pendidikan yang berpengaruh, akses informasi serta akses ke rana publik lebih 
menunjang seperti hampir semua lowongan pekerjaan banyak terdapat perempuan. Dengan banyaknya lowongan pekerjaan yang terdapat perempuan menyebabkan perempuan bisa bekerja demi menambah kebutuhan keluarga, sehinggaberkurangnya ketergantunganperempuan atau istri terhadap laki-laki atau suami”.

\section{Proses Perubahan Fungsi dalam Institusi}

\section{Keluarga}

Semakin banyaknya angka perceraian yang terjadi pada saat ini, dimana angka perceraian terus mengalami peningkatan dari tahun ke tahun, hal ini menunjukkan terjadinya perubahan pada fungsi-fungsi keluarga saat ini (Rr. Tjahyani B : 2004), yaitu fungsi biologis, fungsi sosialisasi/pendidikan, fungsi ekonomi, fungsi pelindung / pemeliharaan, fungsi penentuan status dan fungsi afeksi.

Fungsi pengaturan Keturunan / fungsi biologis, bagi keluarga khususnya suami istri adalah pemenuhan kebutuhan biologis atau hubungan suami istri, kebutuhan ini adalah kebutuhan lahiriyah sekaligus batiniyah, bukan hanya melahirkan anak saja. Kebahagiaan keluarga dalam teori sosiologi ada teori fungsional, dimana keluarga adalah sebagai sebuah sistem dan apabila dalam sistem itu ada bagian yang tidak berfungsi, maka terjadilah disfungsional dalam keluarga yang mengakibatkan kurang harmonisnya keluarga bahkan tidak jarang terjadinya perceraian. Hal inilah yang menunjukkan adanya perubahan dalam fungsi biologis, para ke 4 informan mengatakan bahwa banyaknya waktu yang dihabiskan diluar rumah menjadikan mereka jarang untuk bertemu pasangan. Dimana hal tersebut dapat menyebabkan terjadinya kemacetan dalam fungsi hubungan biologis.

Fungsi sosialisasi / pendidikan, menunjukkan peranan keluarga dalam membentuk kepribadian anak.Melalui interaksi sosial dalam keluarga itu anak mempelajari polapola tingkah laku, sikap, keyakinan, cita-cita dan nilai-nilai dalam masyarakat dalam rangka perkembangan kepribadiannya. Hasil penelitian mengenai perubahan fungsi sosialisasi / pendidikan disini menunjukkan bahwa terdapat adanya perubahan dalam fungsi tersebut,Seperti halnya yang diungkapkan oleh ibu Laili berikut ini;

"saya bekerja sebagai staf pada sebuah perusahaan dimalang, sekarang anak saya berusia 4 tahun dan bersekolah di play group dekat rumah. Kalau saya berangkat kerja pengasuhan anak saya berikan pada orang tua, karena banyak waktu yang saya habiskan ditempat kerja, jadi tidak mungkin saya mempunyai banyak waktu untuk mengajari apa lagi tiap kali saya pulang kerja, kondisi saya sudah capek saat pulang kerumah. Jadi saya jarang untuk bercengkrama bersama anak kecuali pada saat libur kerja, baru saya bisa bersama anak.Oleh sebab itu dalam masalah pendidikan terhadap anak, saya lebih menyerahkan sepenuhnya kepada kakek atau neneknya dan sekolah karena disitu diajarin mengaji, membaca, menyanyi, cara tata krama, sopan santun dan lain-lain".

Bila kita lihat ke masa lalu, tanggung jawab keluarga dalam pendidikan moral dan 


\section{Noken Vol. 6 (No. 1) Halaman: 63-74 2020}

pendidikan sekolah lebih besar dibanding dengan sekarang ini. Pada saat ini dengan banyaknya seorang istri/ibu bekerja diluar rumah demi menambah kebutuhan keluarga dapat menyebabkan bimbingan terhadap anak terhambat, karena selama mereka (ibu/istri) bekerja, dalam hal pengasuhan, pengawasan dilingkungan sekitar dan bimbimbingan belajar terhadap anak sebagian besar dilakukan oleh kakek dan neneknya, walaupun banyak yang membantu dalam melakukan fungsi pendidikan/sosialisasi seperti paman dan bibi yang juga berperan dalam membimbing belajar anak.

Fungsi ekonomi, aktivitas dalam fungsi ekonomi berkaitan dengan pencarian nafkah, pembinaan usaha, dan perencanaan anggaran biaya, baik penerimaan maupun pengeluaran biaya keluarga.Kondisi zaman pada saat ini yang menuntut kebutuhan keluarga samakin besar sehingga membuat perekonomian keluarga menjadi macet dan hasilnya para istri turut serta membantu kebutuhan keluarga.Sama seperti yang telah dijelaskan, para informan juga melakukan tindakan pemenuhan kebutuhan ekonomi dalam membantu perekonomian keluarga, sebab hasil yang didapat oleh suami masih belum mencukupi kebutuhan keluarga karena semakin hari kebutuhan semakin meningkat dan lagi suami jarang ataupun sudah tidak memberikan nafkah kepada istri.
Fungsi pelindung dan pemeliharaan, keluarga berperan sebagai benteng terhadap seluruh anggota keluarga dari gangguan fisik maupun psikis, baik dari segi keamanan keluarga maupun kesehatan keluarga, dalam hal ini fungsi tersebut banyak tergantikan atau diambil alih oleh Negara maupun perusahaan, seperti dari segi keamanan yang lebih banyak tergantikan oleh badan-badan keamanan social dari pemerintah seperti polisi dan dari segi kesehatan banyak digantikan oleh tempat-tempat kesehatan, seperti rumah sakit, puskesmas, klinik bersallin, dan jaminan kesehatan social yang diberikan oleh perusahaan untuk para karyawannya serta badan-badan social seperti panti jompo, panti asuhan juga anak cacat tubuh dan mental.

Fungsi penentuan status, Penentuan status yang diperoleh seseorang didalam lingkungan masyarakat yang bukan didapat sejak lahir tetapi diberikan karena usaha dan kepercayaan masyarakat seperti kepala suku, ketua adat, sesepuh dan sebagainya dan penentuan status yang diperoleh sejak lahir seperti jenis kelamin, ras, kasta, keturunan, suku, usia dan lain sebagainya

Fungsi afeksi, Hubungan afeksi tumbuh sebagai akibat adanya hubungan cinta kasih yang menjadi dasar perkawinan serta kebutuhan dasar manusia dalam memperoleh kasih sayang. Oleh sebab itu rasa kasih sayang harus selalu kita jaga dan kita pupuk, sebab bisa terjadi kasih sayang itu surut bahkan hilang sama sekali. Hal itu bisa 


\section{Noken Vol. 6 (No. 1) Halaman: 63-74 2020}

terjadi, karena saling tidak memahami fungsifungsi di dalam keluarga, suami atau istri yang bekerja di luar rumah dan jarang bertemu bisa menyebabkan lunturnya kasih sayang, jika kasih sayang tersebut sudah luntur maka bisa jadi dalam hubungan keluarga baik istri ataupun suami dan juga anak akan mencari kasih sayang diluar. Seperti yang diungkapkan oleh ibu annisa 36 tahun dan ibu may 36 tahun berikut ini;

"Dahulu suami sangat sayang dengan keluarga, akan tetapi dengan berjalannya waktu selama kurang lebih 8 tahun, rasa kasih sayang suami terhadap keluarga, saya rasakan sudah tidak seperti dahulu lagi, apalagi sejak dia kenal dengan judi, dia sudah jarang sekali pulang dan dia lebih suka bersama teman-temannya dari pada bersama dengan keluarganya dirumah".

"Suami saya adalah orang yang menurut saya suami yang sayang akan keluarga walau pun saya seorang janda beranak 1 , akan tetapi dengan berjalannya waktu bersama suami selama 6 tahun, suami sudah mulai berubah, rasa kasih sayang terhadap keluarga serasa memudar dan sudah tidak seperti dahulu lagi, suami sering keluar rumah kalau saya berada dirumah dan lagi suami lebih memilih bersama teman-temannya dari pada bersama saya dan anak dirumah".

Berbagai fungsi - fungsi keluarga yang dijelaskan diatas oleh informan menunjukkan bahwa dalam institusi keluarga telah terjadi suatu perubahan pada fungsi - fungsi keluarga itu sendiri. Jadi bila ditemui dalam suatu keluarga telah terjadi suatu perselisihan atau konflik dalam hubungan rumah tangga, maka bukan hanya salah satu fungsi-fungsi tersebut diatas saja yang tidak dapat berjalan dengan baik, karena jika salah satu fungsi tersebut mengalami masalah maka akan merembet kepada fungsifungsi lainnya.

\section{Makna Perceraian Bagi Wanita Bercerai}

Masyarakat pada saat ini relatif telah mentoleransi terjadinya perceraian, maka perceraian bukan lagi suatu hal yang memalukan dan tabu untuk dilakukan, maka ketika wanita mengalami masalah perkawinan dan menemukan alasan untuk bercerai, keputusan berceraipun ditempuh sebagai salah satu jalan untuk menyelesaikan kemelut keluarga yang terjadi. Stigma umum terhadap perceraian dalam kehidupan bermasyarakat pada saat ini semakin berkembang dan kemungkinan berkaitan dengan makna perceraian (Fachrina \& Aziwarti,2006) dalam masyarakat yang juga mengalami pergeseran. Selanjutnya dari gambaran jawaban semua informan yang telah diwawancarai tentang bagaimana sesungguhnya mereka memaknai perceraian itu sendiri, maka dapat di identifikasi beberapa makna perceraian antara lain:

\section{Perceraian Dianggap Sebagai Langkah/Jalan}

\section{Keluar Dari Masalah.}

Makna terhadap perceraian oleh informan muncul karena hampir semua informan dalam proses kehidupan perkawinan mereka sebelumnya memang tidak luput dari berbagai masalah yang melahirkan konflik dan pertengakaran terus menerus. Mereka tidak dapat 


\section{Noken Vol. 6 (No. 1) Halaman: 63-74 2020}

lagi mencari jalan keluar yang terbaik dan memuaskan bagi mereka berdua (pasangan).

Pertengkaran dan perselisihan yang terjadi terus menerus membuat istri memilih untuk bercerai dari suamiya dikarenakan tidak tahan dengan semua cacian, makian, hinaan dan fitnah yang ia terima selama ini,ditambah lagi terdapat adanya kekersan non fisik yang mana membuat istri menderita lahir dan batin sehingga membuat istri berani untuk memutuskan untuk mengakhiri hubungan yaitu bercerai. sebagaimana yang diungkapkan oleh informan bernama mila dan annisa berikut ini;

"Saya sudah mencoba untuk bertahan dengan semua keadaan yang terjadi antara saya dan suami, saya sudah mencoba bermacam cara agar hubungan kami tidak berakhir tapi hasilnya tidak ada perubahan dari suami, setiap hari tidak ada sekalipun tanpa pertengkaran hanya karna saya menanyakan sesuatu hal yang bagi saya itu biasa (uang belanja) tapi tanggapannya malah suami marah, menghina dan lebih lagi menfitnah saya, dari pada saya bertahan terus tanpa suatu kepastian yang tidak jelas mending kita pisah saja karena ini yang terbaik buat kita berdua".

"Saya sudah mengiklaskan semua, makanya saya memutuskan saat ini untuk bercerai, untuk apa dipaksa kalau akan membuat batin menderita, dimana tiap hari bertengkar dan tidak jarang saya kena marah bahkan sampai memukul, itu kalau suami biasanya ada masalah atau kalah dalam berjudi. Saya sudah sering menasehati akan tetapi tidak dihiraukan. Jadi untuk apa dipaksa kalau batin menderita, entar lama-lama saya tinggal tulang sama kulit".

Dalam keadaan yang demikian adanya, situasi dan kondisi perkawinan itu sendiri tidak lagi mampu menciptakan keharmonisan, dan keberlangsungan perkawinan yang tidak dapat untuk terus dilanjutkan.Bercerai menjadi alternatif yang dianggap dan diyakini oleh informan sebagai satu jalan keluar, Bagi mereka lebih baik bercerai, hidup tanpa dengan pasangan (suami) dari pada hidup dalam suatu perkawinan yang tidak membahagiakan.

\section{Makna Kebebasan}

Bebas dari beberapa peran yang harus dijalani selama masa perkawinan, artinya dapat dikatakan pada umumnya mereka merasakan bebas dari kekuasan suami dan beban yang dirasakan serasa menghilang karena semua informan yang terdiri dari 4 orang menyatakan bahwa mereka sudah berusaha semaksimal mungkin dan bahkan lebih, agar suami bisa bahagia seperti apa yang diharapkan, akan tetapi suami jarang untuk bisa menghargai niat baik istri dan perjuangan istri untuk mencoba mempertahankan hubungan, karena para suami masih beranggapan bahwa istri yang ideal ialah istrinya patuh terhadap suami, menyesuaikan diri dengan sikap suami dan iklas menggurus rumah tangga tanpa melihat keadaan dan kondisi istri. Meskipun 4 informan diantaranya adalah wanita yang bekerja dan 1 informan tidak bekerja, seorang istri mungkin dapat dikatakan memberikan kontribusi terhadap munculnya pemberian makna kebebasan ini.

\section{Perceraian Merupakan Makna Kemandirian}




\section{Noken Vol. 6 (No. 1) Halaman: 63-74 2020}

Fenomena gugatan cerai yang terjadi sebelumnya, dimana istri pada umumnya sangat tergantung pada nafkah yang diberikan suami, maka di sini terlihat adanya pergeseran karena sekarang perempuan tidak lagi tergantung pada suami baik secara ekonomis maupun psikologis. Sebagai mana dengan yang di ungkapkan oleh informan bernama annisa 36 tahun;

"Bahwasannya saya meminta cerai dari suami karena sudah tidak tahan lagi dalam perkawinan yang tidak membahagiakan, sebab suami tidak pernah berfikir tentang kebutuhan rumah tangga dan masa depan anak kita. Suami selalu meminta uang kepada saya tiap kali dia kalah dalam berjudi, ditambah lagi saya harus membayar atau mengangsur hutang-hutang suami, maka lebih baik saya hidup sendiri sebab suami bisa menghidupi dirinya sendiri tanpa bantuan saya dan saya pun bisa hidup sendiri karena saya mempunyai pekerjaan yang setidaknya dapat memenuhi biaya kebutuhan saya dan anak setiap harinya".

Selanjutnya ditempat yang terpisah, peneliti menanyakan hal yang sama kepada salah satu informan yang pada saat mengambil keputusan untuk bercerai mereka belum bekerja dan masih bergantung ekonomi pada suami sebab adanya pemberian kebutuhan ekonomi dari orang lain. Sebagai mana yang diungkapkan oleh informan bernama laili berikut ini;

"Saya meminta cerai dari suami karena sudah tidak tahan dengan kelakuan suami yang suka semena-mena ditambah lagi suami sudah malas untuk bekerja dan sudah tidak pernah memberi nafkah serta sering marah-marah dengan alasan yang tidak jelas. Maka dari itu saya memutuskan untuk bercerai dari suami sebab saya merasa bahwa saya masih bisa memberi makan anak walaupun saya harus tinggal bersama orang tua saya kembali sebab orang tua saya lah yang selama ini memberikan sumbangan tambahan biaya hidup kita berdua".

Dengan demikian jika ditemui dalam perkawinan sesuatu yang membuat perkawinan tidak bisa lagi dipertahankan maka faktor ekonomi bukan lagi menjadi satu-satunya alasan mereka untuk tidak memutuskan mengambil langkah perceraian. Bagi para informan baik yang bekerja ataupun tidak, perceraian merupakan perwujudan dari aspek kemandirian mereka, seperti halnya penjelasan terhadap makna kebebasan di atas.

\section{KESIMPULAN}

Berdasarkan hasil penelitian tentang Fenomena gugatan cerai dikalangan istri terhadap suami pada Pengadilan Agama Kabupaten Malang, maka dapat ditarik kesimpulan bahwa tindakan yang dilakukan oleh kalangan istri dalam gugatan cerai terhadap suami, mempunyai makna sebagai jalan keluar dari masalah, makna kebebasan, dan makna kemandirian, dari makna perceraian tersebut terdapat adanya variasi faktor penyebab terjadinya perceraian, akan tetapi faktor tersebut bukanlah faktor tunggal melainkan satu rangkaian sebab, yang membuat informan memutuskan untuk menempuh proses perceraian.

Hal ini juga juga di dukung oleh adanya pergeseran nilai social budaya dalam masyarakat berupa toleransi terhadap perceraian, dimana perceraian bukan lagi hal yang tabu untuk 
dilakukan dan terjadinya perubahan fungsi keluarga, yang mana kewajiban yang harusnya lebih banyak dilakukan oleh orang tua, sekarang ini lebih banyak diserahkan kepada pihak lain.

\section{DAFTAR PUSTAKA}

Burhan Bungin (2007),Penelitian Kualitatif: komunikasi, ekonomi, kebijakan public danilmu social lainnya. Jakarta: Kencana.

Karim, Erna (1999), Pendekatan Perceraian dari Perspektif Sosiologi. Dalam Ihromi, Bunga Rampai Sosiologi Keluarga. Jakarta: Yayasan Obor Indonesia.

Pengadilan Agama Kabupaten Malang. 2010 2014

Su'adah,2005, Sosiologi Keluarga, Universitas Muhammadyah Malang, Malang.

Soerjono Soekanto, 2009, Sosiologi Keluarga, RinekaCipta, Jakarta

Sugiyono (2011), Metode Penelitian Kuantitati Kualitatif Dan R\&D. Bandung: Penerbit Alfabeta.

Taufik Rohman Dhohiri (2007), Sosiologi 2 Suatu Kajian Kehidupan Masyarakat. Jakarta : Yudhistira.

Sumber dari internet:

Muh.Akbar, 2010. Sosiologi Keluarga (Perspektif Sosiologis Mengenai Perceraian) http://muhakbarsyukur.blogspot.com/2012/09/perspektifsosiologi-mengenaiperceraian.html(Diakses padatanggal 5 April 2014)

\section{Sumber Dari Jurnal :}

Bakhtiar Hasan A.M (2009). Perceraian Dan Perubahan Sosial Di Kabupaten Bungo (Studi terhadap Tren Pola Perceraian dari Talak Cerai ke Gugat Cerai) Kontekstualita Vol. 26 No. 2. Desember.

Fachrina \& Aziwarti, (2006). Perubahan NilaiNilai Perceraian di kalangan Wanita
Bercerai (Studi terhadap istri yang cerai gugat dalam masyarakat Minangkabau kontemporer). Laporan Penelitian Kajian Wanita.

Nur Aisyah (2013), Relasi Gender Dalam Institusi Keluarga (Pandangan Teori Sosial Dan Feminis), Muwazah, Vol. 5, No. 2, Desember.

Rr. Tjahyani B (2004), Perubahan Fungsi Sosiologi Keluarga Didesa Asal Migran Tenaga Kerja Wanita (TKW).

\section{PROFIL SINGKAT}

Penulis, Siti Nurul Nikmatul Ula, lahir di Desa Wonokerto, Kecamatan Bantur, Kabupaten Malang, Jawa Timut (JATIM), pada tanggal 29 Juli 1986. Pada jenjang pendidkan tinggi penulis mengikuti studi pada Jurusan Manajemen Perusahaan di Fakultas Ekonomi, Universitas Gajayana Malang yang diselesaikan pada tahun 2009. Sebelum melanjutkan studi, penulis bekerja di Gramedia Malang, Penerbit Buku Kanisius dan Andi Offset,Warung Spesial Sambal Malang 01. Selanjutnya penulis melanjutkan studi S2 Pascasarjana Sosiologi Komunikasi, Universitas Muhammadiyah Malang, selesai pada tahun 2016. Dan aktifitas sekarang yang dijalani sebagai Dosen tetap Universitas Muhammadiyah Sorong. 